\title{
Circulating Endothelial Cells: Realities and Promises in Vascular Disorders
}

\author{
Francoise Dignat-Georgea, José Sampola, Gregory Lipb, \\ Andrew D Blann b
}

aUMR INSERM 608, Laboratoire d'Hematologie et Immunologie, University of Marseille, France

bHaemostasis Thrombosis and Vascular Biology Unit, University Department of Medicine, City Hospital, Birmingham UK

Key Words

Circulating endothelial cells · Cardiovascular disease

\section{Abstract}

Endothelial contribution to human vascular disorders is difficult to investigate, owing to the paucity of non-invasive methods and of specific endothelial markers. Circulating endothelial cells (CECs) might be used as a surrogate non-invasive marker for the study of vascular alterations. To address this problem, we produced an antibody against the endothelial molecule CD126 (S-Endol) and developed, in the nineties, an original and sensitive immunomagnetic separation assay. Using this approach, we demonstrated elevated number of CECs in clinical diseases linked with vascular injury like heart catheterization, sickle cell anemia, bacterial infection, thrombotic thrombocytopenic purpura or acute coronary syndromes. CECs correspond to very rare cells present in blood since levels in the range of 3 cells $/ \mathrm{ml}$ are detectable in these pathologies. Several clinical interest of CECs will be discussed including their relevance as marker of disease activity, severity or treatment efficacy, or their use in diagnostic tests. The origin of endothelial cells in peripheral blood is difficult to establish. They could correspond to endothelial cells dislodged from the vessels in response to injury. It was subsequently shown that a

\section{KARGER}

Fax +4161306 1234

E-Mail: karger@karger.ch www.karger.com
C 2004 S. Karger AG, Basel $1424-8832 / 04 / 0336-0495 \$ 21.0 / 0$

Accessible online at: www.krager.com/pht subset of CECs comprised a population of bone marrow-derived endothelial progenitors that participate in angiogenesis. Identification of the origin and characteristics of CECs provides fascinating insights into endothelial cell pathophysiology. Moreover, CECs constitute original and promising tools for diagnosis, prognosis and therapy of vascular disorders.

Copyright () 2004 S. Karger AG, Basel

\section{Introduction}

The endothelium is one of the largest organs of the body, consisting of more than $10^{14}$ cells lining the vascular tree. Strategically located between blood and tissues, the endothelium plays a crucial role in the control of several fundamental responses such as haemostasis, blood pressure regulation and angiogenesis [1]. The structural and functional integrity of the endothelium is essential for the maintenance of vascular homeostasis, and loss of function leads to thrombosis, hypertension and oedema. Endothelial function can be assessed by the measurement of soluble markers, such as von Willebrand factor (vWf) released into the blood, and by physiological techniques such as flow mediated dilatation [2]. Although endothelial cells themselves were first demonstrated in the blood over 30 years ago (hence circulating endothelial cells (CECs)), they have been recog-

Pr Francoise Dignat-George PhD

UMR INSERM 608, Laboratoire d'Hematologie et Immunologie, University of Marseille, France

Tel/Fax + 334918356 02; E-mail: dignat@pharmacie.univ-mrs.fr 
nised only recently as an additional marker for assessing vascular integrity [3].

The objective of this article is to 1 ) review the current status of CECs, 2) document methodological issues adapted to the concept of rare events, 3) examine pathological situations associated with CECs and their value in clinical medicine, and 4) consider the origin of CECs.

\section{Circulating Endothelial Cells: from the Concept of Rare Events to Technical Issues}

Bouvier and Hladovec were the first to report the presence of non-hematopoietic cells of possible endothelial origin in human blood. On the basis of morphology, intact nucleated cells were recovered in leukoconcentrates by Bouvier et al [4] whereas anuclear "carcasses" were detected in platelet rich plasma by Hladovec [5]. Several authors subsequently described similar cells in different models of endothelial damage such as shock by E. Coli endotoxin in animals [6], or smoking, acute myocardial infarction, immunosuppression, hypertension and homocysteinaemia in man [7-11]. However, divergent results were reported by these groups, due to the variety of cell fractions studied, cell identification by morphology, and methods of cells concentration, based on physical properties such as size or density.

Like tumour cells or trophoblast cells, CECs belong to the population of rare non-hematopoietic cells present at a very low frequency in peripheral blood. Their accurate detection has to fulfil at least two prerequisites: cell enrichment of these rare cells from whole blood using a sensitive method, and subsequent identification with a specific endothelial marker. We addressed these requirements by using an immunophysical method combining cell enrichment and specific labelling by the use of magnetic beads coupled to a monoclonal antibody (S-Endo1) directed against the endothelial antigen CD146 [12]. This adhesion molecule belonging to the Ig superfamily is largely distributed on all types of endothelial cells but is not detectable on hematopoietic cells $[13,14]$. CD146 is concentrated at the endothelial junction where it plays a key role in the control of cell-cell cohesion, permeability and signalisation $[15,16]$. Briefly, magnetic dynabeads coated with anti-CD146 monoclonal antibody are mixed with venous blood in a head over head mixer. Unbound cells are washed out with buffer, bound cells are retained by a magnet. Cells forming rosettes with the beads are recovered in two fractions, used respectively for CEC counts and subsequent phenotypic characterization. CECs are identified according to size and number of

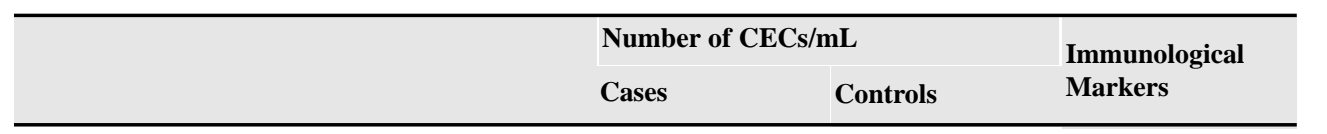

Tab. 1. Reports of CECs in case/control studies of vascular disorders

\section{Cardiovascular disease}

Coronary angioplasty $[17,19]$

Acute coronary syndromes [20]

Sickle cell anaemia [21]

Pulmonary hypertension [22]

Peripheral vascular disease [23, 42]

Haematological and infectious disease

Rickettsial infection [24]

Cytomegalovirus infection [18, 25]

Septic shock [26]

Immune injury

Thrombotic thrombocytopenia [27]

Behcet's disease [28]

Systemic lupus erythematosus [29]

Inflammatory vasculitis [31]

Kawasaki disease [32,39]

Transplantation

Bone marrow transplantation [35, 44]

Renal transplantation [32-34]

Cancer

Breast cancer, lymphoma [36]

$\begin{array}{lll}6-10 & <3 & \text { HEC } 19 \\ 7.5 & 0 & \text { CD } 146 \\ 13.2-22.8 & 2.6 & \text { CD } 146 \\ 30 & 3.5 & \text { CD } 146 \\ 1.1-3.5 & 0.9 & \text { CD } 146\end{array}$

$\begin{array}{lll}5-1,600 & <3 & \\ 45 & 4 & \text { CD } 146 \\ 16.1 & 1.9 & \text { vWF }\end{array}$

$6-220<3$

$0-25<3 \quad$ CD 146

$32 \quad 5 \quad$ CD 146

$136 \quad 5 \quad$ CD 146

$15 \quad 6 \quad$ CD 146

16-44 8 CD 146

24-72 $6 \quad$ CD 146

6,800-39,100 2,00-7,900 CD 146

CD 34

CD 45 
beads bound (i.e. more than 10 beads bound to cells of 20 $50 \mu \mathrm{m}$ diameter). The endothelial nature of cells isolated by the beads is confirmed by vWf expression and lack of expression of leukocyte antigens such as CD45. Thus using anti-CD146 antibody and immunomagnetic separation, we unequivocally demonstrated that CECs exist and can be detectable in peripheral human blood [19,20], a technique now widely adopted in a wide variety of conditions. Other endothelial-associated markers such as endoglin [17] or vWf have been used by other groups [18]. An alternative to the immunobeads method is flow cytometry [36] were blood is labelled antiendothelial monoclonal antibodies.

\section{Pathological Settings Associated with CECs}

In humans, CECs have been detected in diverse conditions of endothelial injury (Table 1). Elevated levels were reported in various cardiovascular disorders, as a result of mechanical injury, ischemic injury or hypertension [17,19,20-23]. Among infectious diseases, high levels of CECs were also reported in pathologies in which the endothelium is the target of pathogens such as Rickettsia [24], cytomegalovirus (CMV) [18, 25] and in septic shock [26]. Increased numbers of CECs have also been described in association with immune disorders (thrombotic thrombocytopenic purpura, Behcet's disease, systemic lupus erythematosus, Kawasaki disease and inflammatory vasculitis [2731]), but also in transplantation [32,35], and in cancer [36]. There is a great variability in the levels of CEC reported in these diseases, ranging from an average of 1.1 to 1600 cell $/ \mathrm{ml}$. Part of this variability can be ascribed to the diverse disease processes as CEC counts vary according to the extent of the endothelial lesion. For example, a high CEC count is found in widespread vascular damage associated with Rickettsial vasculitis, sickle cell crisis, or CMV infection. In contrast, the number of CECs found in localized vessel damage such as coronary angioplasty only slightly exceeds the normal range. Of more concern is the variety in CEC levels in healthy controls, showing good agreement in groups using immunomagnetic beads and CD146, with values lower than 10 cells/ml [17-35]. In contrast, using the same immunological markers and flow cytometric detection, greater numbers of CEC (up to 1000-fold higher than the immunobeads methods) were detected in cancer patients and their relative controls [36].

Thus the literature clearly indicates that CECs are now considered as a marker to assess (mural) endothelial injury [19-24,27-38] However, the discrepancies of data obtained using immunomagnetic separation versus flow cytometry argues in favour of standardized methodologies.

Circulating Endothelial Cells in Vascular Disorders

\section{Potential Value of CECs in Clinical Medicine}

Since the level of CECs is very low in normal individuals, elevated levels represent a non-invasive marker of potential use in documenting endothelial alterations on a quantitative basis. In various situations, the longitudinal quantification of CEC showed that levels vary according to the clinical evolution, with a good relationship with disease severity. Several studies in the literature demonstrated that CEC levels in patients who are acutely ill are higher than those in patients in clinical remission or in recovery phase of the disease. For example, CECs are higher in acute myocardial infarction than in angina [20], and are higher in critical limb ischaemia than in intermittent claudication [23]. The iterative monitoring of CECs in sickle cell patients showed that their level increases at the onset of painful episodes, suggesting their predictive value of acute crisis [21]. In patients with Mediterranean spotted fever, the most elevated values were detected in patients with malignant forms who developed thrombotic complications [24]. A strong correlation between CEC numbers and disease severity was reported in patients with inflammatory vasculitis, whereas CEC numbers fell when patients were in remission [32]. Apart from this prognostic value, the CEC count can also have a diagnosis value, in combination with other biological markers. In patients with non ST elevation acute coronary syndrome, a multi-marker strategy combining CEC count and troponin level increases the number of patients diagnosed within the six first hours after chest pain (Personnal data).

From a pharmacological point of view, CEC level can be used to monitor the efficiency of the therapy. Renal transplant recipients who received cyclosporine had higher number of CEC than their age and creatinine matched counterparts who did not receive these drugs [32]. In the same manner, high CEC counts were reported in patients being pre conditioned for allogenic bone marrow transplantation with total body irradiation and cytotoxic agents, cyclophosphamide and busulphan [35]. A working hypothesis is that mural endothelial cells are detached as a result of injury induced by condition regiment. In contrast, in patients with thrombocytopenic purpura, plasma exchange in combination with vincristine results in lower CEC counts [27].

In addition to the quantitative aspect, the analysis of the phenotypic and function of CEC potentially provides useful informations since CECs are submitted to the same environmental stimuli and blood born activating factors that vessel wall endothelium. Phenotypic analysis of CEC is also useful to determine whether they circulate in an activated state. For example, tissue-factor is expressed on CECs from patients with acute coronary syndromes or sickle cell anaemia $[20,38]$ suggesting that they may participate in the activation of tissue factor pathway. Whether or not this

Pathophysiol Haemost Thromb 2003/2004;33:495-499 
property is clinically important is unknown but it is tempting to speculate that some CECs do indeed contribute adversely to the disease process by activating prothrombotic pathways. In addition, regardless of clinical status, most CECs from sickle cell patients express adhesive receptors for leucocytes (ICAM-1, VCAM-1, E selectin), suggesting that the endothelium they come from adopts a pro-inflammatory phenotype [21]. Interestingly sulfasalazine, an inhibitor of NFK, significantly reduced the expression of adhesion molecules in CECs from patients and from sickle transgenic mice [38]. This pilot study indicates that not only the number but also the level of activation of CECs can be used to evaluate the effectiveness of drug therapy targeted to diseases of the endothelium. Therefore, more than a noninvasive marker of endothelial injury, CECs may represent an opportunity to study endothelial phenotype and functions and thus explore endothelial associated vascular disorders.

\section{Origin of Blood Endothelial Cells}

A key question is to know from which anatomical region CECs are detached. CD36 labelling has been used to determine whether or not CECs arise from micro- or macro-vessels. CD36 positivity indicated that CECs were mainly of micro-vessel origin in sickle cell patients [21] and cancer (36], whereas none of the CECs recovered in acute coronary syndromes stained for CD36, suggesting that they detached from large vessels [20]. It is tempting to speculate that the increased number of CECs following acute myocardial infarction arises from the coronary arteries or from the chambers of the heart, but no clear data are available. An important future development will be to analyse tissue specific markers to target the anatomical site of vessel injury.

Although we have focussed up to now on CECs that may likely arise from mural endothelial cells, there is another population of endothelial-like cells found in the blood that may arise from the bone marrow [39]. Knowledges accumulated these 15 last years, indicates that the endothelium is a tissue with a high plasticity in equilibrium between 3 different compartments, vessel wall endothelium, blood endothelium cells, and bone marrow endothelium cells defining a reservoir of Progenitor Endothelium Cells (PECs) [46]. These cells may be recruited in response to angiogenic stimuli, such as VEGF, ischemia or vascular trauma. They are mobilized in the peripheral blood where they become circulating (CEPs) and home to sites of neovascularization. These CEPs can be discriminated from CECs on the basis of phenotypic and functional characteristics. Indeed, they are defined by the co-expession of immaturity markers (CD133) and endothelial markers such as CD31, VE-cadherin, and are characterized by an ability to form in vitro colonies with a high proliferative potential $[39,40]$. One function of these CEPs may be to replace CECs damaged or destroyed by a pathological process(es). Identification of the origin of blood endothelial cells may facilitate the use of these cells in clinical diagnosis and biomedical applications [41].

\section{Conclusions}

Increased number of CECs in various diseases reflects severe vascular disturbance and may contribute adversely to the disease process. In contrast, CEPs may play a key role in the regenerative response of the vessels and represent an excellent autologous biomaterial source for cell-based therapeutic application, as already demonstrated in the treatment of ischemic disorders. These different subpopulations of blood endothelial cells open fascinating new directions in the study of endothelial injury and repair.

\section{References}

1 Cines DB, Pollak ES, Buck CA, Loscalzo J, Zimmerman GA, McEver RP, Pober JS, Wick TM, Konkle BA, Schwartz BS, Barnathan ES, McCrae KR, Hug BA, Schmidt AM, Stern DM. Endothelial cells in physiology and in the pathophysiology of vascular disorders. Blood 1998; 91 : 3527-3561.

$\checkmark 2$ Blann AD. Endothelial cell activation, injury, damage and dysfunction: separate entities or mutual terms? Blood Coagul Fibrinolysis 2000 11: 623-630.

3 Dignat-George F, Sampol J. Circulating endothelial cells in vascular discorders : new insights into an old concept. Eur J Haematol 2000:65;215-220.

4 Bouvier CA, Gaynor E, Cintron JR, Bernhardt B, Spaet TH. Circulating endothelium as an indicator of vascular injury. Thromb Diath Haemorrh 1970:40(Suppl):163-168.

5 Hladovec J, Rossman P. Circulating endothelial cells isolated together with platelets and the experimental modification of their counts in rats. Thromb Res 1973:3;665-674.
6 Gaynor E, Bouvier CA, Spaet TH. Circulating endothelial cells in endotoxin treated rabbits. Clin Res 1968;16:535

7 Prerovsky I, Hladovec J. Suppression of the desquamating effect of smoking on the human endothelium by hydroxyethylrutosides. Blood Vessels 1979:16;239-240.

8 Hladovec J, Prerovsky I, Stanek V, Fabian J. Circulating endothelial cells in acute myocardial infarction and angina pectoris. Klin Wochenschr 1978:56;1033-1036.

$\checkmark 9$ Hladovec J, Jirka J, Prerozsky I, Malek P. Decrease of endothelaemia during immunosuppression. Biomedicine 1976;25:204-206.

10 Hladovec J, Prerovsky I. Endothelial lesion in hypertension. Cor Vasa 1989;31:51-54.

11 Hladovec J, Sommerova Z, Pisarikova A. Homocysteinaemia and endothelial damage after methionine load. Thromb Res 1997;88:361-364.
12 George F, Poncelet P, Brisson C, Laurent JC, Arnoux D, Massot O and Sampol J. Isolation of Endothelial cells from whole blood with S-Endo 1 coated magnetic beads. Magnetic separation techniques applied to cellular and molecular biology. Edited by Dr John - Kemshead p 223-224.

13 Bardin N, George F, Mutin M, Brisson C, Horschowski N, Frances V, Lesaule G, Sampol J. S-Endo 1, a pan-endothelial monoclonal antibody recognizing a novel human endothelial antigen. Tissue Antigens 1996;48: 531-539.

14 Bardin N, Frances V, Lesaule G, Horschowski N, George F, Sampol J. Identification of the S-Endo 1 endothelial-associated antigen. Biochem Biophys Res Comm. 1996;218:210-216.

15 Bardin N, Anfosso F, Masse JM, Cramer E, Sabatier F, Le Bivic A, Sampol J, Dignat-George F. Identification of CD 146 as a component of the endothelial junction involved in the control of cellcell cohesion. Blood 2001;98:3677-3684. 
16 Anfosso F, Bardin N, Vivier E, Sabatier F, Sampol J, Dignat-George F. Outside-in signaling pathway linked to CD146 engagement in human endothelial cells. J Biol Chem 2001;276:1564-1569.

17 Sbarbati R, de Boer M, Marzilli M, Scarlattini M, Rossi G, van Mourik JA. Immunologic detection of endothelial cells in human whole blood. Blood 1991;77:764-769.

18 Percivalle E, Revello MG, Vago L, Morini F, Gerna G. Circulating endothelial giant cells permissive for human cytomegalovirus (HCMV) are detected in disseminated HCMV infections with organ involvement. J Clin Invest 1993;92:663670.

19 George F, Brisson C, Poncelet P, Laurent JC, Massot O, Arnoux D, Ambrosi P, Klein-Soyer C, Cazenave JP, Sampol J. Rapid isolation of human endothelial cells from whole blood using S-Endo1 monoclonal antibody coupled to immuno-magnetic beads: demonstration of endothelial injury after angioplasty. Thromb Haemost 1992;67:147-153.

20 Mutin M, Canavy I, Blann A, Bory M, Sampol J, Dignat-George F. Direct evidence of endothelial injury in acute myocardial infarction and unstable angina by demonstration of circulating endothelial cells. Blood 1999;93:2951-2958.

21 Solovey A, Lin Y, Browne P, Choong S, Wayner E, Hebbel RP. Circulating activated endothelial cells in sickle cell anemia. N Engl J Med 1997;337: 1584-1590.

22 Bull TM, Golpon H, Hebbel RP, Solovey A, Cool CD, Tuder RM, Geraci MW, Voelkel NF. Circulating endothelial cells in pulmonary hypertension. Thromb Haemost 2003;90:698-703.

23 Makin A, Chung NAY, Silverman SH, Blann A, Lip GY. Assessment of endothelial damage in atherosclerotic vascular disease by quantification of circulating endothelial cells. Eur Heart J 2004:25;371-376.
24 George F, Brouqui P, Boffa MC, Mutin M, Drancourt M, Brisson C, Raoult D, Sampol J. Demonstration of Rickettsia conorii-induced endothelial injury in vivo by measuring circulating endothelial cells, thrombomodulin, and von Willebrand factor in patients with Mediterranean spotted fever. Blood 1993;82:2109-2116.

25 Grefte A, Van Der Giessen M, Van Son W, The H. Circulating cytomegalovirus (CMV)-infected endothelial cells in patients with an active CMV infection. J Infect Dis 1993;167:270-277.

26 Mutunga M, Fulton B, Bullock R, Batchelor A, Gascoigne A, Gillespie JI, Baudouin SV. Circulating endothelial cells in patients with septic shock. Am J Respir Crit Care Med 2001;163:195200.

27 Lefevre P, George F, Durand JM, Sampol J. Detection of circulating endothelial cells in thrombotic thrombocytopenic purpura. Thromb Haemost 1993;69:522.

28 Camoin-Jau L, Kone-Paut I, Chabrol B, Sampol J, Dignat-George F. Circulating endothelial cells in Behcet's disease with cerebral thrombophlebitis. Thromb Haemost 2000;83:631-632.

29 Clancy R, Marder G, Martin V, Belmont HM, Abramson SB, Buyon J. Circulating activated endothelial cells in systemic lupus erythematosus: further evidence for diffuse vasculopathy. Arthritis Rheum 2001;44:1203-1208.

30 Woywodt A, Schroeder M, Mengel M, Schwarz A, Hambroz M. Circulating endothelial cells area around marker of cyclosporine induced endothelial damage. Hypertension 2003;41:720-723.

31 Nakatani K, Takeshita S, Tsujimoto H, Kawamura Y, Tokutomi T, Sekine I. Circulating endothelial cells in Kawasaki disease. Clin Exp Immunol 2003;131:536-540.

32 Woywodt A, Streiber F, de Groot K, Regelsberge $\mathrm{H}$, Haller H, Haubitz M. Circulating endothelia cells as markers for ANCA-associated small-vessel vasculitis. Lancet 2003;361:206-210.
33 Woywodt A, Schroeder M, Gwinner W, Mengel M, Jaeger M, Schwarz A, Haller H, Haubitz M. Elevated numbers of circulating endothelial cells in renal transplant recipients. Transplantation 2003;76:1-4.

34 Popa ER, Kas-Deelen AM, Hepkema BG, van Son WJ, The TW, Harmsen MC. Donor-derived circulating endothelial cells after kidney transplantation. Transplantation 2002:74;1320-1327.

35 Woywodt A, Scheer J, Hambach L, Buchholz S, Ganser A, Haller H, Hertenstein B, Haubitz M. Circulating endothelial cells as a marker of endothelial damage in allogeneic hematopoietic stem cell transplantation. Blood 2004;103:36033605.

36 Mancuso P, Burlini A, Pruneri G, Goldhirsch A, Martinelli G, Bertolini F. Resting and activated endothelial cells are increased in the peripheral blood of cancer patients. Blood 2001;97:36583661.

37 Quilici J, Banzet N, Paule P, Meynard JB, Mutin $\mathrm{M}$, Bonnet JL, Ambrosi P, Sampol J, DignatGeorge F. Circulating endothelial cell count as a diagnostic marker for non ST elevation acute coronary syndrome. Circulation, In press

38 Solovey A, Gui L, Key NS, Hebbel RP. Tissue factor expression by endothelial cells in sickle cell anaemia. J Clin Invest.1998;101:1899-1904

39 Asahara T, Murohara T, Sullivan A, Silver M, van der Zee R, Li T, Witzenbichler B, Schatteman G, Isner JM. Isolation of putative progenitor endothelial cells for angiogenesis. Science 1997;275:964967.

40 Shi Q, Rafii S, Wu MH, Wijelath ES, Yu C, Ishida A, Fujita Y, Kothari S, Mohle R, Sauvage LR, Moore MA, Storb RF, Hammond WP. Evidence for circulating bone marrow-derived endothelial cells. Blood 1998;92:362-367.

41 Rafii S, Lyden D, Benezra R. Vascular and haemopoietic stem cells: novel target for anti angiogenesis therapy. Nat Rev Cancer 2002;2:826-835. 